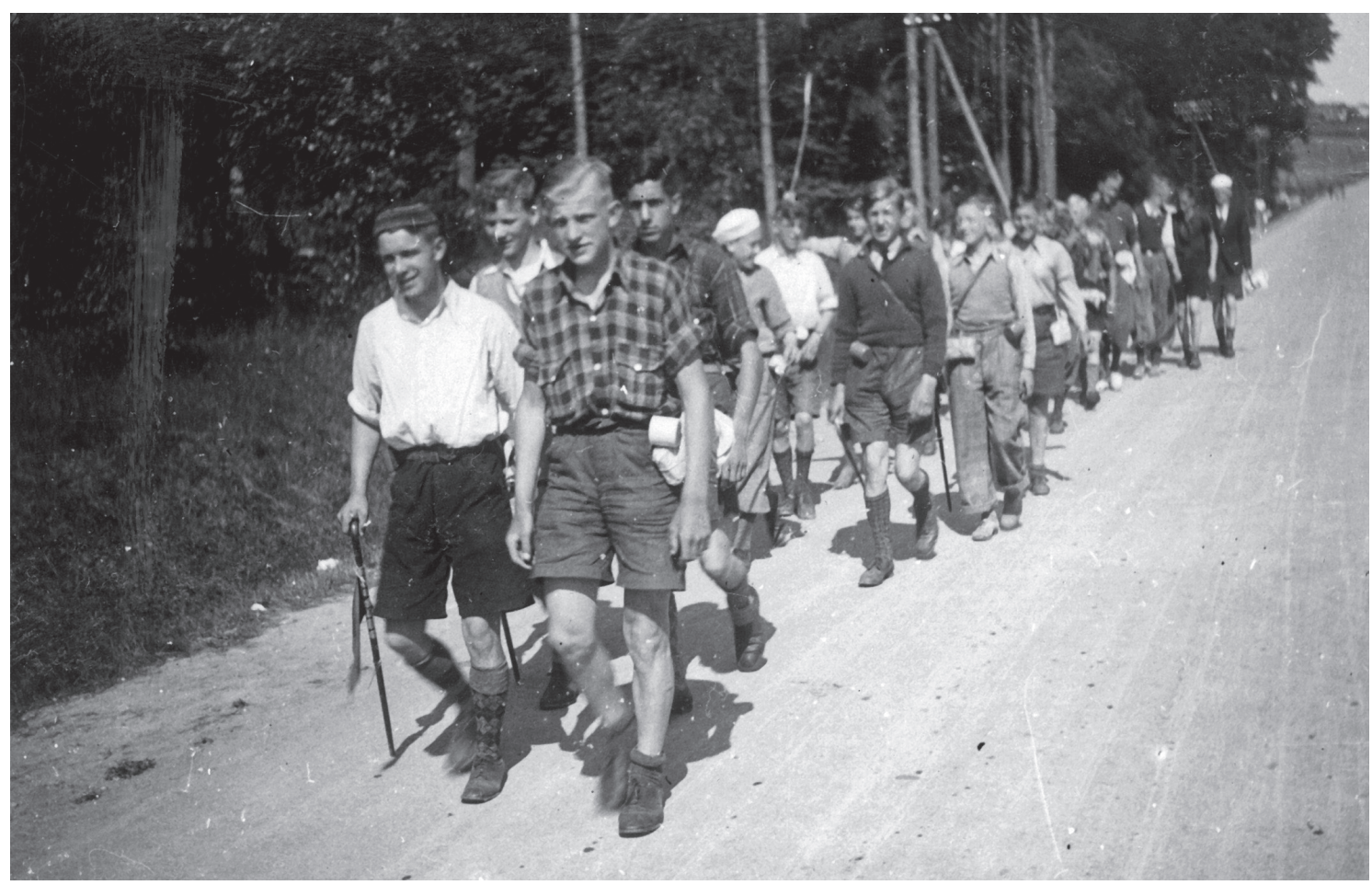

Raske drenge på vandring i 1930'ernes Danmark (Odense Stadsarkiv).

\title{
The missing link
}

- om vandrebevæegelse og mangel på samme i Danmark 
Fra Kilpisjärvi i det nordlige Finland til Alexandroupolis i Grækenland går en europæisk vandrerute. Den samlede distance udgør 5200 kilometer. Vandrestien eller Fjernvandrevejen E6, som den bliver kaldt, er imidlertid ikke helt intakt. Der er et brud på stien. Ruten går ikke tværs over Fyn. Det er man først ved at gøre noget ved nu. Dansk Vandrelaug, der har ansvar for stien i Danmark, har nu indgået et samarbejde med Naturturisme i Svendborg ${ }^{1}$, og vandreforbindelsen er ved at blive etableret. Spørgsmålet er: Hvorfor er fjernvandrerutens "missing link« i Danmark? Og hvorfor sker der først noget nu?

I vore nabolande er det at tage på længere vandreture meget udbredt. Sådan forholder det sig imidlertid ikke i Danmark. I denne artikel sættes med afsæt i fjernvandreruten fokus på, hvad det er der gør, at vi i Danmark ikke har samme vandrekultur som i vore nabolande.

Vi har tidligere haft tradition for at tage på længere traveture i Danmark. I 1930 blev Dansk Vandrelaug under påvirkning fra bl.a. de Tyske Vandrefugle i Tyskland etableret, og en vandrebevægelse voksede frem. Ungdommen drog væk fra storbyens larm og jag ud på landet, hvor den syngende vandrede fra vandrerhjem til vandrerhjem (Hansen, 1938). Denne tradition er forsvundet. I dag er det meget få mennesker, der i Danmark tager på vandretur med overnatning på vandrerhjem. Artiklen søger med udgangspunkt i fjernvandreruten og Sydfyn at belyse de forhold, der spiller ind for de trange kår, vandrebevægelsen har og har haft i Danmark. Casen "the missing link" og Sydfyn er her valgt som afsæt, fordi et af de centrale forhold knyttet til udbredelse af vandrekultur handler om vandrernes adgang til naturen. The "missing link" ligger i det område, hvor man i øjeblikket disku- terer på Sydfyn, om man skal have en nationalpark ${ }^{2}$. Den er der ikke enighed om, og det betyder, at interessemodsætninger kommer op til overfladen, synspunkter brydes, og kampe om adgang til naturen udspilles. Kampe, der reelt har betydning for befolkningens adgang til naturen og dermed også muligheder for friluftslivsudøvelse.

Vandrekulturen har og har haft det svært men der er også noget nyt i gære - fjernvandrerutens missing link forsvinder nu, ligesom en lang række nye vandreruter opstår i disse år. En ny vandrebølge er på vej i landet.

Jeg vil i det følgende først sætte fokus på det konkrete område på Horneland, hvor fjernvandreruten ikke går. Formålet er at give et billede af kultur- og friluftslivslandskabet og belyse de landskabsmæssige forhold, der danner rammerne for menneskets bevægelsesmønstre i området i dag. Så går jeg tilbage og belyser den vandrekultur, der i Danmark opstod i tyverne og trediverne. Siden diskuterer jeg, hvad det er, der bevirker, at denne vandrekultur forsvandt. Der peges på forandringsprocesser i kulturlandskabet som følge af bl.a. rationaliseringer i landbruget, og jeg sætter fokus på den rolle, som organisationerne spiller eller ikke spiller i understøttelsen af vandrekulturen. I Norge satser de store friluftsorganisationer på turfriluftsliv, imens dette fokus ikke er til stede i Danmark. Til sidst ser jeg på den kamp, der lige nu føres om adgang til naturen på Sydfyn. På dette felt har lodsejere og jægere traditionelt haft stor magt, men nu er bosætning og naturturisme blevet vigtige politiske og økonomiske temaer, og derfor er det sandsynligt, at adgangsmulighederne til naturen vil forbedres, vandretiltag understøttes og vandrekulturen blomstre i de kommende år. 


\section{MISSING LINK LANDSKABET, PUNKTFRILUFTSLIV}

\section{OG TURFRILUFTSLIV}

I efteråret 2009 indgik Naturturisme I/S og Dansk Vandrelaug, der har ansvar for fjernvandreruten i Danmark, en aftale om at udbedre "The missing link«. Man besluttede sig for at få den sidste strækning af den 5.200 kilometer lange fjernvandrerute i mål. I første omgang kommer fjernvandreruten dog ikke til at følge den rute, som Dansk Vandrelaug ønskede. Dansk Vandrelaug ønsker, at ruten skal følge det, man kan kalde det "naturlige" forløb, der er at lade ruten gå fra Bøjden på Horneland og Vestfyn ind mod Faaborg, hvor den der kan fange Øhavsstien $^{3}$ og følge den mod Svendborg, hvorfra den så kan fortsætte op til Nyborg. Imidlertid verserer der i øjeblikket en nationalparkdebat i området. Det betyder, at landskab er i spil, og forskellige organisationer, partier, politikere og enkeltpersoner har positioneret sig i en kamp om det fremtidige landskab. Naturturisme I/S er en væsentlig deltager i dette spil, og Naturturisme I/S ønsker at vælge sine kampe med omhu og vurderer derfor, at det i øjeblikket er forbundet med for store politiske omkostninger at kæmpe for en sti, der fra Horneland skal gå ind at fange Øhavsstien. (Bøje, 2010).

Fjernvandreruten kommer i stedet til at gå fra Fynshav på Als til Ærø. Herfra følger den allerede etablerede øhavssti til Ærøskøbing, hvor fra den fortsætter med færgen til Svendborg og videre mod Nyborg.

Lad os kigge nærmere på "Missing link landskabet« Horneland. Det landskab hvor stien ikke går og heller ikke kommer til at gå. Formålet er at tegne et billede af landskabet, adgangsmulighederne til landskabet og den nuværende friluftslivsudøvelse på Horne. Det er interessant at belyse, hvorfor det er svært at tage fat på at anlægge en sti her samt undersøge, hvad en sti

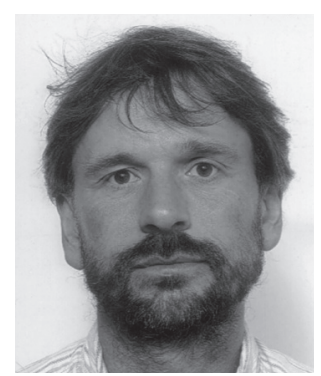

AF

JAKOB HAAHR

kan betyde for området. Da man ikke for alvor har forsøgt at etablere en sti på Horne, kan jeg ikke sige noget om, hvordan man konkret forholder sig til en sti her. I stedet peger jeg på nationalparkdebatten og de konfliktinteresser, der er i den forbindelse, og bruger dem som udtryk for lodsejerholdninger og andre stimodstandsholdninger på Sydfyn og resten af Danmark.

Horneland er en halvø beliggende vest for Faaborg omgivet af Sønderfjord, Lyø Krog og Faaborg Fjord. Jordbrugslandskabet på Horneland er som de fleste andre steder i privat eje og drevet rationelt af et moderne dansk landbrug (Faaborg-Midtfyn kommune, 2008). Der er store monokulturmarker med begrænset biologisk mangfoldighed, og det er paradoksalt, at artsdiversiteten er større i storbyen (Agger, 2:2002). Der er få stier i landskabet. Ældre kort fortæller, at der tidligere har været mange små markveje og stier forbundet i et tæt netværk, men de er ligeledes forsvundet på grund af landbrugets rationaliseringer. (Højkantskort 1880, Lavkantskort 1930, 4 cm kort 1953, Skærmkort 2008, 2010)

På kysten er der allemandsret, imens den private ejendomsret råder inde i landet. På Horneland findes de rekreative naturområder hovedsageligt ved kysten, og dem er der mange af. Det friluftsliv, der hovedsageligt udøves, kan vi kalde punktfriluftsliv. Punktfriluftslivet er det friluftsliv, der, når det udøves, er knyttet til et be- 
grænset område i begrænset tid. Det kan være en lille skov, et fugleområde, en friluftsgård, en fiskeplads eller en badestrand. På Horneland holder ornitologerne og de andre fuglekiggere til i et fugleområde "Bøjden Nor «, hvor der bl.a. er etableret et fugletårn. Badegæsterne finder vi ved færgehavnen.

Øst herfor holder erhvervs- og fritidsfiskerne til på fritidshavnen, og siden kommer blåflagsstranden ved Bøjden Camping. Længere inde i bugten befinder sommerhusgæsterne sig i et stort sommerhusområde.

På campingpladsen, der er femstjernet, holder familierne og børnene til. Der er vandland, moderne minigolf, minitog, blåflagsaktiviteter, restaurant, cafe, spillehal, kiosk og meget mere. Campingpladsen er et moderne feriecenter, og sloganet er: "Fordi ferien ikke kan gøres om" (Bøjden Camping, 2010). Der er ingen eller kun få, der vandrer frem til campingpladsen. Der er heller ingen naturlige stier til campingpladsen, ligesom der på pladsen kun er små telte, i hvilken der overnatter cyklende eller vandrende. Her udøves moderne punktfriluftsliv med meget høj komfort. Bøjden Camping har som de fleste andre campingpladser i landet valgt at gå "stjernevejen«. Den har fem stjerner og har således bevæget sig mod luksus og væk fra det enkle campingliv.

Hvert landskab på Horne har sine friluftsbrugere, og landskaberne er kun infrastrukturelt forbundet via det asfalterede vejnet. Der er ingen stiforbindelser mellem disse områder tværtimod er campingpladsen hegnet godt ind, og derfor er det heller ikke så enkelt at komme til blåflagstranden, ligesom der heller ikke sammenhængende stier ind i landet og langs kysten.

Punktfriluftslivet ved kysten på Horneland har altså relativt gode kår, men det friluftsliv, som foregår inde i landet, og turfriluftslivet, er ikke så godt stillet. Med turfriluftslivet mener jeg det mobile friluftsliv, der foregår over større områder eller over længere tid. Dette turfriluftsliv, hvor man er af sted i flere timer eller dage, er der mange, der har oplevet nogle særlige kvaliteter ved. Kvaliteterne kan være forskellige, men ofte relaterede de sig til en særlig samværsform, der giver oplevelser af fællesskab. Derudover er det naturoplevelse, naturindlevelse, kulturindsigt og perspektiv på hverdagslivet, som mennesker typisk nævner, når de priser dette turfriluftsliv (Tordsson, 2006). Det var turfriluftsliv, som vandrebevægelsen i 30'erne var bygget op omkring, og det er det friluftsliv, som Den Norske Turistforening med stor succes har sat fokus på helt frem til i dag.

Det er ikke kun på Horneland, at adgangen til naturen er blevet mindre. En undersøgelse fra området omkring Vejle viser, fra 1950 til 1988 er mere end $40 \%$ af alle veje og stier blevet sløjfet (Højring \& Caspersen, 1999), og der er bred enighed om, at tendensen er landsdækkende (Frilufstrådet, 2009). Den enstrengede produktionsform i landbruget bevirker, at marker sammenlægges og stier pløjes op, udyrkede arealer hegnes ind, og den øgede bilisme og det større vejnet skaber sammen med byernes vokseværk endnu flere gestaltbrud i landskabet (Agger, 2:2002).

Observationerne om turfriluftsliv over for punktfriluftsliv genspejles i de kvantitative data. Ifølge Frank Søndergaard Jensen kommer $96 \%$ af den danske befolkning ud i landskabet mindst en gang om året. Blandt dem er der 91 procent, der kommer i skoven, og her er den hyppigste aktivitet at gå tur. To tredjedele af samtlige skovbesøgende går tur i skoven. (Søndergard Jensen, Koch, \& Tvedt, 2005, s. 227) Danskerne vandrer altså meget og det under- 
streges da også af Maja Pilgårds tal, der viser at vandring er den motionsaktivitet, der udøves mest i Danmark. Men i Pilgaards egen analyse fremgår det, at respondenterne med vandring ofte forstår gåtur (Pilgaard, 2007). Kigger vi nærmere på Frank Søndergaard Jensens tal, så understøtter de, selv om dette er skovtal, også de nævnte betragtninger. Det er hovedsageligt punktfriluftsliv, der udøves. Den længere vandretur - den tur der varer i mere i 2 timer, er der i følge Frank Søndergaard Jensen ikke mange der udøver (Jensen, Koch, \& Tvedt, 2005). Det at vandre, det at tage på tur i det danske landskab, det at gå fra sted til sted med rygsæk og overnatte på henholdsvis vandrerhjem, campingplads eller primitiv overnatningsplads, er ikke særlig udbredt længere.

\section{TURVANDRING I NORGE OG DANMARK}

At det står dårligt med turvandringen i Danmark, får vi også en indikation på, når vi ser på medlemstal og aktivitet blandt de organiserede vandrere i Danmark. Vandrerne er internationalt organiseret i European Ramblers Organisation. Denne har mere end 5 millioner medlemmer i 26 europæiske medlemslande (European Ramblers Association, 2010). I Danmark er vandrerne hovedsageligt organiseret i Dansk Vandrelaug, der har omkring 10.000 medlemmer. ${ }^{4}$ Til sammenligning har pendanten i Norge, Den Norske Turistforening, 232.000 medlemmer. DNT har altså mere end 23 gange så mange medlemmer på trods af, at der bor færre mennesker i Norge end i Danmark (Den Norske Turistforening, 2010).

Selvfølgelig er der forskel på de to landes natur og friluftstraditioner. Den norske turistforening (DNT) er væsentlig ældre end Dansk Vandrelaug. DNT er stiftet i 1868, mens Dansk Vandrelaug er fra 1930, men det er værd at be-

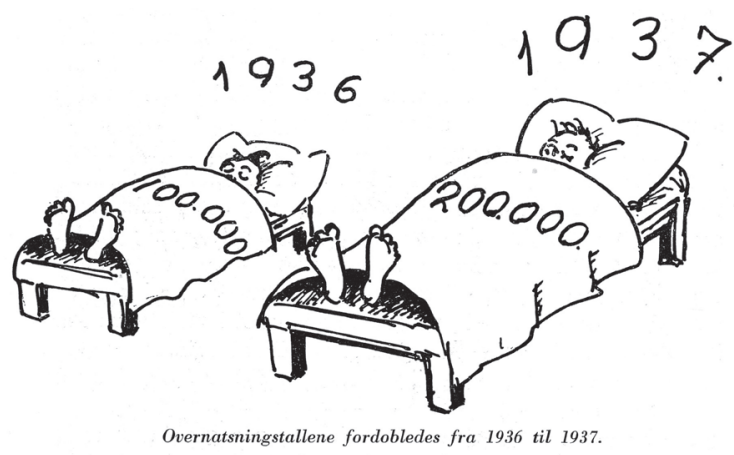

Tal fra Vandrebevægelsens Udvikling i Danmark

\begin{tabular}{|r|r|r|r|r|r|r|r|r|}
\hline & 1930 & 1931 & 1932 & 1933 & 1934 & 1935 & 1936 & 1937 \\
\hline $\begin{array}{c}\text { Antal udst. Vandre. } \\
\text { kort _......... }\end{array}$ & 300 & 584 & 1829 & 3080 & 6646 & 11685 & 21487 & 37487 \\
$\begin{array}{r}\text { Antal Vandrehjem. } \\
\text { Antal Overnatnin- } \\
\text { ger _.......... }\end{array}$ & 60 & 96 & 115 & 122 & 124 & 153 & 166 & 190 \\
Antal Sengesteder. & 1430 & 18000 & 31000 & 34000 & 41000 & 57000 & 107000 & 196000 \\
\hline
\end{tabular}

Vandrebevægelsens vækst kom også til udtryk gennem overnatning på vandrehjem. Antallet af overnatning blev næsten fordoblet fra 1936 til 1937 (Gengivet efter Poul H. Jakobsen: Dansk Vandrelaug, 1938).

mærke, at i 30'erne, da vandrebevægelsen havde en opblomstringsfase, var de to organisationer omtrent lige store. I 1932 skriver doktor P. Bjartnes i det norske DNT-blad: "... Vi må opp i minst 20.000, og det er min faste overbevisning, at vi kan nå det tall meget snart, hvis vi bare mannjevnt vil det« (Den Norske Turistforening, 2010). Til sammenligning var der 50.000 medlemmer i Dansk Vandrelaug i 1938 (Hansen, 1938).

Når man sammenstiller de to lande, er der selvfølgelig nogle forskelle, man må tage i betragtning. I Norge har man relativ meget fri natur, og Den Norske Turistforening holder primært til på fjeldet. I de senere år har den også 


\section{Dansk Vandrelaugs Vækst}

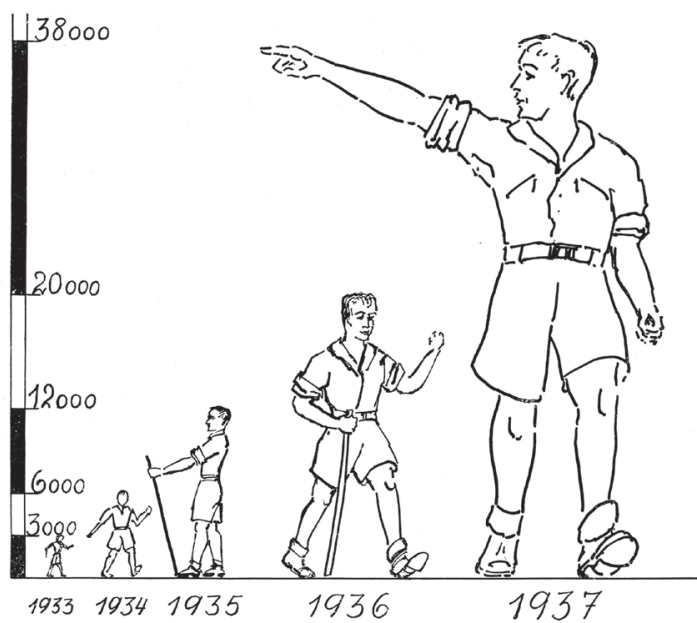

Dansk Vandrelaug voksede stot i 1930'erne. I 1938 rundede foreningen 50.000 medlemmer (Gengivet efter Poul H. Jakobsen: Dansk Vandrelaug, 1938).

bevæget sig ned fra tinderne, og den arbejder nu bl.a. på at etablere stier over alt.

I Norge har man fået både børnene og de unge med. Der er 20.000 medlemmer i "Barnas Turlag«, der er for børn mellem 0 og 12 år. Her laver man typisk bivuakture, overnatningsture, spøgelsesture, skærgårdslejr og bedsteforældreture. De unge i DNT har også mere end 20.000 medlemmer. Disse får tilbud om at komme med på mange ture og profitere på billigere hytteovernatning. Kerneaktiviteten for organisationens medlemmer er rygsæksvandringer. I Den Norske Turistforening er det turen og turfriluftslivet, der er i centrum. DNT-medlemmer går fra hytte til hytte og overnatter $i$ hytterne på fjeldet.

I Dansk Vandrelaug er der derimod en skæv aldersfordeling. Der er stiftet ungdomsgrupper, men de unge er her mellem 30 og 45 år (Mentze,
2005). At dømme efter Dansk Vandrelaugs aktiviteter synes det som om, at det primært er punktfriluftsliv, dens organisation og medlemmer udøver. I Dansk Vandrelaugs medlemsblad for marts og april 2010 annonceres en række vandreture. De vandreture, der udbydes i Danmark, og som vi kan kalde turfriluftsliv, fylder en side i deres medlemsblad. Til sammenligning udgør punktarrangementerne, dvs. de korte vandreture, mere end 40 sider (Fritidsliv - medlemsblad for Dansk Vandrelaug, 2010).

\section{HISTORISK TILBAGEBLIK}

Den danske og norske vandrebevægelse var omtrent lige store i 30'erne. Men de to bevægelser kom til at udvikle sig i hver sin retning. I Norge blev der stor fokus på turfriluftsliv, stiafmærkning, hytteudbygning og oplæring til turfriluftsliv, og bevægelsen blev stor. I Danmark, hvor landskabet har en anden karakter, kom der ad åre hovedsageligt fokus på punktfriluftslivet, og den vandrekultur, der egentlig havde været vandrebevægelsens fundament, og som havde fokus på overnatning på vandrehjem, aftog.

I 1930'erne opstod der særlig under inspiration fra Tyskland en usædvanlig vandrekultur, som meget hurtig blev udbredt over hele landet, og med ferielovens indførelse var der skabt et behov for meningsfyldt udnyttelse af ferie og fritid (Mentze, 2005, s. 13). Vandrebevægelsens succes knyttedes i høj grad op til det at etablere vandrehjem. Efter tysk forbillede stiftede fire store danske organisationer - Danmarks Socialdemokratiske Ungdom, De Unges Idræt, International Ungdomsliga og Det Danske Spejderkorps - Herbergsringen i 1930 (Holm, s. 30). Bag sammenslutningen lå en tanke om at skabe et net af overnatningssteder, som de unge kunne basere deres vandreture på (Holm, s. 30). Dansk Vandrelaug, der også stiftedes i 1930, kom hur- 
tigt med i denne ring, hvor den hurtig blev den største aktør. Dansk Vandrelaug fik en enorm succes, og i 1940 havde den således 60.000 medlemmer (Mentze, 2005).

Samarbejdet mellem organisationerne om etableringen af vandrerhjemmene var en af hovedårsagerne til vandrebevægelsens succes. Stig Hansen, der var stifter af Dansk Vandrelaug, skrev i 1938, at Dansk Vandrelaug sammen med Herbergsringen havde sejret med deres hovedopgave, der i fællesskab har været at etablere:

1) Gode, hygiejniske vandrehjem i tilstrækkeligt antal ud over hele Danmark

2) God orden, renlighed og overholdelse af det fastsatte reglement

3) Dygtige og ansvarsbeviste værter

4) Vandrere med en sådan optræden, at forældre altid kan føle sig trygge ved at vide de unge på vandretur (Hansen, s. 22)

Dansk Vandrelaug, Herbergsringen og vandrehjemmene formåede at udvikle og understøtte en kulturform, hvor det at vandre dannede rammer om en særlig samværsform med fokus på natur, bevægelse, sang og fællesskab. Om Søllerød Vandrerhjem skriver Stig Hansen eksempelvis: "Her skabtes D.V.L.'s særlige, kammeratlige, smukke Aand og Tone, bl.a. ved Laugsaftenerne, som straks indførtes derude«. Til disse arrangementer havde fællessangen en særlig stor betydning (Hansen, s. 20). Dansk Vandrelaug var desuden dygtige til at samarbejde og agere politisk. Man havde eksempelvis et tæt samarbejde med turistorganisationerne og Naturfredningsforeningen, der på dette tidspunkt også en havde en friluftsprofil, idet man bl.a. havde sit eget lejrudvalg (Jakobsen, 1938).

Efter krigen gik det ned ad bakke for Dansk
Vandrelaug og vandrebevægelsen. I 1955 fik bilister også adgang til vandrerhjemmene, men gående og cyklende havde fortrinsret til sovepladserne. Vandrerhjemmene, der var kerneaktiviteten i DVL i de første mange år, måtte Dansk Vandrelaug efterhånden afhænde, og med dem forsvandt et mødested og en samværsform.

Michala Mentze skriver i festskriftet Fodnoter, der udkom i forbindelse med Dansk Vandrelaugs 75 års fødselsdag i 2005, "at Dansk Vandrelaug er en organisation, der har formået trods dalende medlemstal at overleve i bedste velgående, og forklaringen er, at den altid har taget tidens puls." (Mentze, 2005, s. 14) Sammenlignet med de andre organisationer er det vist en sandhed med modifikationer. Alt for sent opdagede foreningen, at skulle man bibeholde en vandrekultur, var det nødvendigt at agere friluftspolitisk og deltage i kampen om adgangen til landet. Først I 1977 blev foreningens forhold til friluftspolitik under formanden Erik Aksvig opprioriteret, og man oprettede et natur- og stiudvalg. Men på det tidspunkt var rationaliseringer og forandringer i Danmark i fuld gang og den friluftspolitiske interesse marginaliseret både i befolkningen og politisk, og sådan gik det også Dansk Vandrelaug.

I dag spiller DVL en ganske ubetydelig rolle, og det paradoksale er, at ingen andre organisationer på turfriluftslivsfeltet har formået at tage over. Det er en dyr fornøjelse at overnatte på vandrerhjem, og det er de færreste, der vandrer fra vandrerhjem til vandrerhjem. På vandrerhjemmene møder man kun sjældent andre vandrere, og kulturen er forsvundet. Aktiv Danmark har lavet en opgørelse, hvor man har spurgt vandrere, hvilken form for overnatning de benytter, når de vandrer lange ture i Danmark. Her er det mest populært at overnatte på 
campingplads, dernæst kommer de primitive overnatningspladser, og først på tredjepladsen kommer vandrerhjemmene. I en samlet analyse, hvor man belyser vandreturisters overnatningsform mere generelt, er der 55 procent af vandreturisterne, der overnatter i feriehus, mens kun 1 procent overnatter på vandrerhjem. (Aktiv Danmark, 2008)

\section{TURFRILUFSTLIV OG KAMPEN OM NATUREN PÅ SYDFYN}

I forbindelse med nationalparkdebatten på Sydfyn foregår der en kamp om naturen. Forskellige brugere, organisationer, politikere og andre interessenter indtager forskellige positioner og deltager nu i en kamp om en eventuel nationalpark og er dermed parter i en kamp om rettigheder til at benytte natur- og kulturlandskabet.

Billedet er i virkeligheden komplekst, men for overskuelighedens skyld kan man tale om tilhængere og modstandere af nationalparken. De magthavende politikere, der har søsat undersøgelsesprojektet, er i udgangspunktet positivt indstillet. Et væsentligt argument for at iværksætte nationalparkundersøgelsen har været politikernes interesse i at øge turismen og styrke bosætningen i området. Derfor bakker turismeindustrien og handelsstandsforeninger også op om projektet. De store organisationer, der bl.a. udgør Danmarks Naturfredningsforening, Friluftsrådet og ornitologerne, er også tilhængere, men ud fra andre grundbetragtninger. De ser muligheder for at skabe, beskytte og få adgang til mere natur.

Modstanderne eller skeptikerne, som mange af dem ynder at kalde sig, er hovedsageligt landmænd, skovejere og mennesker, der ønsker at have naturen for sig selv. Landmændene, skovejerne og jægerne har traditionelt brugt og forvaltet naturen, og de er bange for konsekvensen af at lade andre grupper benytte den selvsamme natur. De er bange for at miste forvaltningsansvar og brugsrettigheder, ligesom nogle af skeptikerne er ængstelige for at blive overrendt af turister. Modstanderne er væsentlige aktører i debatten. 70 procent af lodsejerne har skrevet under på, at de er modstandere af parken, og ca. 2/3 af alle debatindlæg i Fyns Amts Avis og Fyens Stiftstidende udtrykker modstandernes holdninger. Modstanderne møder op og deltager på borgermøder og i arbejdsgrupper, og når de $\mathrm{i}$ forskellige arbejdsudvalg skal stemme om en endelig indstilling til styregruppen, trommer de fæller sammen. Her forsøger man at forhindre, at der etableres en nationalpark eller i det mindste begrænser dens udbredelse, så den kun indbefatter øhavet og ikke også skov- og landbrugslandet.

Der er altså modstand mod friluftsliv og turfriluftsliv - men hvordan forholder det sig med tilhængerne?

Der er i forbindelse med nationalparkprojektet ud fra principper om borgerinddragelse nedsat fire arbejdsgrupper, der skal arbejde med henholdsvis natur, kultur, friluftsliv og erhvervsudvikling i en eventuel kommende nationalpark. Friluftslivet har altså fået en central betydning. Men det er et paradoks, at bortset fra Friluftsrådet, er der ingen organisationer, der i nationalparkprojektet har været $\mathrm{i}$ stand til at i varetage turfriluftslivet og turvandrernes interesser.

I styregruppen for nationalparken, der er udnævnt af Naturturisme I/S, og som skal være med til at forestå en indstilling til politikerne, er de fleste større organisationer repræsenteret, men Dansk Vandrelaug har ikke formået eller haft ressourcer til at få sæde i denne. Stier er på dagsordenen, men stidebatten føres af andre parter, der ikke har stier som primære mål, og måske er det derfor, at Fjernvandreruten E6 er 
et ukendt fænomen på Sydfyn. Fjernvandrevejen er ikke nævnt i de debatter og i det materiale, der er blevet ført i forbindelse med nationalparkprojektet (Nyeland, 2009). Den er heller ikke nævnt i noget af det friluftspolitiske materiale, der er forelagt styregruppen, og som skal danne grundlag for politikernes beslutninger (Blanner, 2010). Der er heller ikke andre organisationer, der i turfriluftslivets tegn har formået at tage over. Dansk Forum for Natur og Friluftsliv er en af de få organisationer, der virkelig har fokus på turfriluftslivet. Men foreningen er lille og har ikke for alvor formået at søge ind på den friluftspolitiske arena, og den har slet ikke for alvor sat fokus på adgang til naturen (Dansk Forum for Natur og Friluftsliv, 2010). Danmarks Naturfredningsforening har heller ikke fokus på turfriluftslivet. Den har tidligere haft et lejrudvalg, men i dag er Naturfredningsforeningens primære fokus knyttet til natur og miljøbeskyttelse.

Naturfredningsforeningens ungdomsorganisation Natur og ungdom har til formål at fremme børn og unges interesse og forståelse for natur og miljø samt at lægge grunden til en varig glæde ved og respekt for naturen. De understreger, at naturoplevelser bør være i højsædet, men de skriver i deres vedtægter og i deres visionsmateriale ikke noget om, hvordan disse naturoplevelser skal opnås. (Natur og Ungdom, 2010). Deres logo er den grønbenede rørhøne. Og det er egentlig ganske symbolsk - den grønbenede rørhøne er lige som Naturfredningsforeningens ungdomsafdeling meget lille og meget svær at få øje på.

Friluftsrådet er den slagkraftige organisation, der kan og skal understøtte turfriluftslivets interesser i forbindelse med nationalparken på Sydfyn. Derfor er det også relevant at se på deres historie og position. Friluftsrådet er en para-

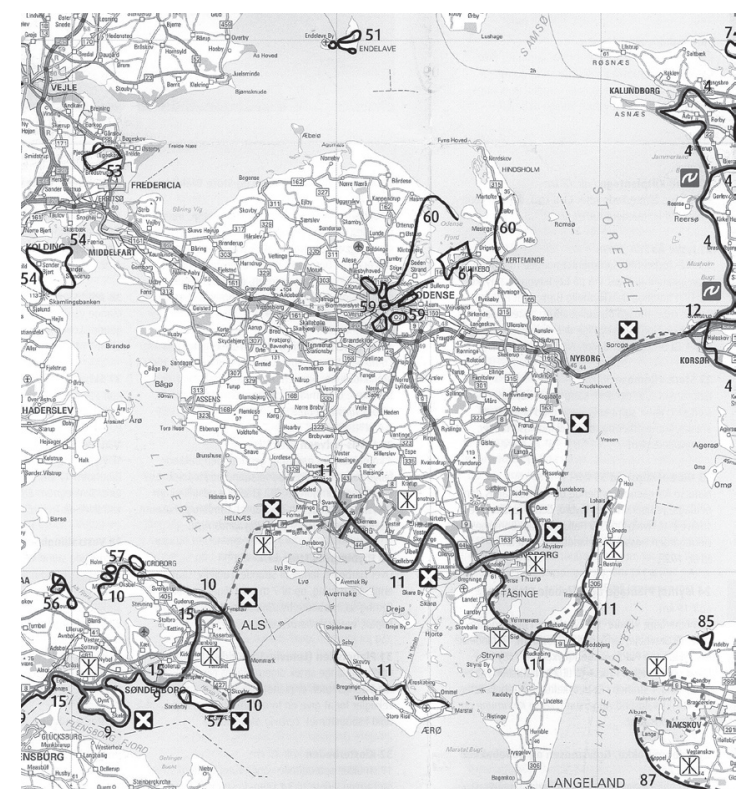

Fjernvandrevejen kommer ikke til at gå over Fyn som skitseret her (den stiplede linje). I stedet for at gå over Horneland kommer Fjernvandrevejen til at gå fra Als over AErø og herfra videre til Svendborg (Kort: Walking Denmark, vandreruter i Danmark).

plyorganisation, der i Danmark varetager friluftslivets interesser. Da den blev stiftet i 1942, var den i det første arbejdsudvalg repræsenteret ved Dansk Cyklistforbund, Herbergsringen, Dansk Vandrelaug, KFUM-spejderne, Dansk Idrætsforbund og lejrklubben for Danmark (Eichberg H. J., 2001). Den var altså repræsenteret ved organisationer, der dengang havde relativt høj fokus på turfriluftslivet. I dag er mere end 100 organisationer medlemmer af Friluftsrådet, og det er en stærk slagkraftig organisation, som også, fordi den administrerer og uddeler nogle af tipsmidlerne både har politisk og økonomisk styrke. Så godt som alle de organisationer, der på den ene eller anden måde bruger 
naturen, er medlemmer. Det betyder også, at næsten al aktivitet, der foregår udendørs, hører ind under Friluftsrådets arbejdsfelt, og af samme grund har man da heller ikke valgt at operere med en essentialistisk friluftsdefinition. Det har den fordel, at Friluftsrådet dermed ikke ekskluderer nogle former for naturbrug, men imidlertid er der også noget, der tyder på, at Friluftsrådet på grund af den brede organisation ikke i tilstrækkelig grad har været i stand til at holde fokus på turfriluftslivet (Friluftsrådet, 2009). Den brede organisation har f.eks. betydet, at bestyrelsen på trods af intentioner ikke har kunnet arbejde mod visionære mål for befolkningens adgang til naturen. Det så vi i 2008, da bestyrelsen i Friluftsrådet på opfordring fra Danmarks Sportsfiskerforbund fremsatte tre adgangspolitiske ønsker:

1) Ret til fladefærdsel i privatejede skove

2) Ret til stilfærdig færdsel langs ledelinjer (diger, hegn, vandløb, bræmmer m.m.) i det åbne land og

3) Ret til at færdes i privatejede skove døgnet rundt (natfærdsel).

Medlemsorganisationernes holdning til emnet fordelte sig fra modvilje til stor opbakning, og så var der en meget stor mellemgruppe. I den adgangspolitiske handlingsplan skrev Friluftsrådet: "Det 'Friluftspolitiske Handlingsprogram"5 og de synspunkter, som dette indeholder, er fortsat grundlaget for Friluftsrådets politik, men på baggrund af det forløbne års debat og på baggrund af de politiske meldinger fra regeringen erkender bestyrelsen, at der pt. ikke synes at være mulighed for at få gennemført vidtgående ændringer af lovgivningen « (Friluftsrådet, 2009). I stedet fremlagde Friluftsrådet et program, hvor de vil arbejde for mindre lovændrin- ger og gøre naturen mere tilgængelig, og så vil de bl.a. gøre arbejdet med at bevare og skabe stier til et særligt indsatsområde.

Selv om ovennævnte problematik ikke direkte handler om stier i landskab og turfriluftsliv, så er det alligevel interessant, for det handler om en stor organisations manøvredygtighed i et politisk spil, og det handler om adgang til naturen og landskabet. Spørgsmålet er, om Friluftsrådet er blevet for stort. Spørgsmålet er, om den som paraplyorganisation er for bred. Det kunne tyde på, at nogle af dens medlemsorganisationer ikke har interesse $\mathrm{i}$ at lempe på befolkningens adgang til naturen, og hvad skal de så der, når de ikke vil arbejde mod mål, der vitterlig kan lempe befolkningens adgang til naturen?

Ovenfor er tegnet et billede af landmænd, skovejere og lokales meget aktive modstand mod nationalparken. Og der er tegnet et billede af friluftsorganisationer, der ikke for alvor har formået aktivt at gå ind og styrke turfriluftslivet. Vinder skeptikerne og lodsejerne så ikke kampen om naturen på Sydfyn?

Det er ikke sikkert. I området på Sydfyn har man før nationalparksdebatten allerede gjort sig nogle erfaringer. Den 220 kilometer lange Øhavssti, der omkranser Det Sydfynske Øhav blev gjort færdig i 2007 og udgør det store gennembrud for stier på Fyn. Det var med Øhavsstien, at der kom politisk forståelse for, at det var vigtigt at have og give penge til stiprojekter. Der opstod en erkendelse af, at ville man trække turisme til området, og vil man øge bosætningen i området, så kunne en farbar vej være en natur- og friluftslivssatsning (Skovhus, 2010). De ni tidligere kommuner i Det Sydfynske Øhav etablerede Naturturisme I/S i 2003, og Øhavsstien opstod som et Naturturismes fyrtårnsprojekt finansieret af Mål 2 midler, amtsmidler og kommunale midler. (Naturturisme IS, 2010) 
I nationalparkdebatten på Sydfyn er det skeptikere og landmænd, der er aktive og har sat sig på mediedebatten, hvor de påvirker befolkningen og politikerne. Omvendt, så er dagsordenen sat af politikerne og Naturturisme I/S, og i styregruppen er de interesseorganisationer, der er positivt stemt over for nationalparken, i flertal. Hvis spørgsmålet kun havde handlet om turfriluftsliv over for landbrug, så havde udfaldet været klart i landbrugets favør. Men pludselig spiller turfriluftslivsinteresser sammen med turisme, sundhed, erhverv og udvikling. Friluftslivet er blevet et turismeprodukt og et redskab til lokal bosætning og et værktøj til sundhedsfremme. Og i det lys er det ikke til at se, hvem der bliver tabere og vindere i kampen om nationalparken.

Selv om Dansk Vandrelaug ikke er en stor slagkraftig organisation, så sker der alligevel noget på vandringsfeltet i disse år. Der etableres bl.a. nye stier. Det er ikke Dansk Vandrelaug, der tager teten, men derimod er det i høj grad myndigheder, der med forskellige dagsordner er i spil. Et af de store projekter, hvor organisationerne ikke har haft nævneværdig indflydelse, er Nordsøstien eller the North Sea Trail, som den også kaldes. Det er en international vandrerute, der har til mål at etablere vandreruter på gamle historiske spor rundt om hele Nordsøen. Redningsveje, kirkestier, drivveje og sejlruter er kædet sammen med natur- og kulturhistoriske seværdigheder. 26 regioner fra Danmark, Norge, Sverige, Tyskland, Holland, England og Skotland medvirker i projektet. Projektet er delvis finansieret af EU igennem interreg-111B programmet, der har til mål at fremme bæredygtig udvikling og forvaltning af miljø, naturressourcer og kulturarv. Derudover har Skov- og Naturstyrelsen og regioner og kommuner været involveret. I Danmark udgør vandreruten 1.500 kilometer. (The North Sea Trail, 2010). Et andet eksempel på vandringskultur på fremmarch finder vi på hærvejen, hvor herbergstanken er blevet relanceret. På Hærvejen er der nu etableret 14 overnatningssteder i landbrugsbygninger. Afstanden mellem overnatningsstederne er overkommelig, og prisen for at overnatte er billig. (Foreningen Herberger langs Hærvejen, 2009)

\section{AFSLUTNING}

Om der bliver nationalpark på Sydfyn, vides ikke. Men stien, der ikke gik tværs over Fyn "The missing link" - kommer. Fjernvandreruten E6 bliver fuldbyrdet. Dansk Vandrelaug og organisationer, der understøtter turfriluftslivet, står med undtagelse af Friluftsrådet overraskende svagt i disse år. Men erhvervsøkonomisk potentiale i kraft af ønsker om turisme og lokal bosætning kombineret med en ny grøn international pilgrimsvandrings- og friluftsbølge, der også bevirker stiprojekter med EU-støtte, vælter ind over landegrænserne. Politikerne har for alvor fået øjnene op for, at der er synergi mellem turisme, bosætning, sundhedsinteresser og kulturog naturhistorisk formidling og friluftsliv.

Der er et stort potentiale for turfriluftsliv i Danmark, og kommunerne, Skov- og Naturstyrelsen og forskellige økonomiske interesser er allerede i gang. Men der mangler en organisation, der kan tale turfriluftslivets sag og interesser. Der er behov for en pendant til DNT i Norge. Friluftsrådet er der, men de har i øjeblikket ikke et eksplicit turfokus, ligesom det måske mangler direkte folkelig forankring. Man kan spørge, hvorfor eksempelvis Danmarks Naturfredningsforening ikke går ind og agerer på dette felt? Hvorfor integrerer den ikke turfriluftsliv i det natur- og miljøpolitiske arbejde? Turfriluftsliv er en eksistentiel vej til at lade befolkningen få interesse for naturen. 
Der er mange årsager til, at Danmark ikke har samme vandrekultur som vore nabolande. Adgangen til naturen er væsentlig sværere i Danmark end i Norge og Sverige. Vi har ikke allemandsret, og i Danmark er det åbne landskab forarmet og rationelt drevet og mange steder uinteressant at vandre i. "Vi vil ud", sang de vandrerne i trediverne. $\mathrm{Nu}$ er der på grund af naturødelæggelse ikke så meget at komme ud efter. I byerne er man for længst i gang med at rydde op efter industrialiseringens forarmelse. Noget kunne tyde på, at tiden er kommet til, at der skal ryddes op på landet efter landbrugets rationelle tidsalder. Heldigvis er der mange friluftspolitiske interesser i spil, og fremtiden peger mod mere natur og friluftsliv og et multifunktionelt landbrug og landmænd med et andet naturforvalteransvar. Der er tegn i sol og måne på, at befolkningen, organisationerne og kommunerne er ved at genopdage turfriluftslivet og glæden ved at færdes på tur i landskabet.

\section{LITTERATUR}

Agger, P. (2:2002). Adgang til landbrugslandet. Geografisk Orientering , s. 398-408.

Aktiv Danmark (2008). Walking Denmark- Aktiv Danmarks Vandreanalyse - Proeferencer og motiver hos danske, tyske og hollandske vandrere. Aktiv Danmark og Institut for Konjunktur-Analyse.

Blanner, P. (2010). Friluftsgruppens rapport til styregruppen, 2. udkast. Svendborg: Nationalparksekretariatet, Sydfyn.

Bourdieu, P. (1996). Refleksiv sociologi - mål og midler. København: Hans Reitzels Forlag.
Bøjden Camping (16. april 2010). Camping, en femstjernet oplevelse. Hentet 16. april 2010 fra Bøjden campings websted: www.bojden.dk

Bøje, R. (9. april 2010). Interview på Vadehavstur. (J. Haahr, Interviewer)

Dansk Forum for Natur og Friluftsliv. (16. april 2010). Foreningen - vedtagter. Hentet 16. april 2010 fra Dansk Forum for Natur og Frilufslivs hjemmeside: www.danskfriluftsliv.dk

Dansk Vandrelaug (marts-april 2010). Fritidsliv - medlemsblad for Dansk Vandrelaug. Dansk

Vandrelaug.

Den Norske Turistforening (17. april 2010). Om DNT- Den norske Turistforening. Hentet 17. april 2010 fra Den Norske Turistforenings websted: http://www.turistforeningen.no

Eichberg, H. J. (2001). De grønne bølger - trak af natur og frilufslivets historie. Vingsted: DGI Natur og Friluftsliv.

Eichberg, H. (2001). Thinking contradictions. Towards a methodology of configurational analysis, or How to reconstruct the societal signification of movement culture and sport. I K. Dietriech, How Societies Create Movement Culture and Sport. Copenhagen: Univercity of Copenhagen.

European Ramblers Association (16. april 2010). The European Ramblers Association. Hentet 16. april 2010 fra European Ramblers Associations websted: www.era-ewv-ferp.org 
Foreningen Herberger langs Hærvejen (2009). Herberger langs hærvejen - Juni, Juli og August 2009. Herbergsfolder. Danmark: Foreningen af Danske Herberger.

Friluftsrådet (2009). Adgangspolitisk Handlingsplan 2007-2010. København: Friluftsrådet.

\section{Fritidsliv - medlemsblad for Dansk Vandrelaug (marts/april 2010).}

Faaborg-Midtfyn Kommune (2008). Friluftsstrategi 2008. Faaborg-Midtfyn Kommune.

Hansen, S. (1938). Dansk Vandrelaugs otte første år. I P.H. Jacobsen, Dansk Vandrelaug Oplysning om den danske vandrebevagelse og dens virke (s. 168). København: Dansk Vandrelaugs Forlag.

Højring, K., \& Caspersen, O. (1999). Landbrug og landskabscestetik - udvklong $i$ landbruget 1950-1995 og dens konsekvenser for landskabets oplevelsesesmaessige indhold. Hørsholm: Skov og landskab.

Haahr, J. (2001). Elvebådene fra Eiker. Odense: Syddansk Universitet.

Haahr, J. (2005). Friluftsliv og levende kulturformidling. I S. Andkjær, Friluftsliv $i$ forandring. Slagelse: Forlaget Bavnebanke.

Jakobsen, P.H. (1938). Dansk Vandrelaug. København: Dansk Vandrelaug.

Mentze, M. (2005). DVL - En forening i tiden Et portræt af Dansk Vandrelaug 1930-2005. I K.W. Meyhoff, Fodnoter - Traek af vandringens hiistorie (s. 207). København: Informations Forlag.
Natur og Ungdom (16. april 2010). Galdende vedtoegter for natur og Ungdom. Hentet 16. april 2010 fra Natur og Ungdoms websted: www. natur-og-ungdom.dk

Naturturisme IS. (14. april 2010). http://www. sydfynskeoehav.dk/index.php?pid=6. Hentet 14 . april 2010 fra Sydfynskeohav.dk: http://www. sydfynskeoehav.dk/index.php?pid=6

Nyeland, J. (2009). Friluftsliv i Det Sydfynske $\varnothing$ hav - en beskrivelse af eksisterende og potentielle muligheder for friluftslivet. Svendborg: 2009.

Pilgaard, M. (2007). Danskernes motions og sportsvaner. København: Idrættens analyseinstitut.

Skovhus, K. (29. marts 2010). Karin Skovhus, Faaborg-Midtfyn Kommune. (J. Haahr, Interviewer)

Søndergard Jensen, F., Koch, N. E., \& Tvedt, T. (2005). Forskning giver friluftsliv bedre muligheder. I: S. Andkjær, Friluftsliv under forandring. Gylling: Forlaget Bavnebakke.

The North Sea Trail. (16. april 2010). Om North Sea Trail. Hentet 16. april 2010 fra North Sea Trails websted: www.northseatrail.org

Thomsen, R. (1938). Sangen i D.V.L. I P.H. Jakobsen, Dansk Vandrelaug (s. 168). København: Dansk Vandrelaug.

Tordsson, B. (2006). Perspektiv på friluftslivets paedagogik. Haderslev: CVU Sønderjylland, University College. 
NOTER

1. Naturturisme I/S er en tværkommunal udviklingsorganisation i Faaborg, Svendborg, Ærø og Langeland Kommu ner. Naturturisme skal styrke turisterhvervets udviklingsmuligheder gennem tiltag, der forbedrer områdets kvaliteter inden for natur og kulturhistoriske oplevelser Interessentskabets virke skal ligeledes styrke grundlaget for kommunernes arbejde for en større bosætning i området. Udviklingen skal ske på et bæredygtigt grundlag $\mathrm{i}$ forhold til lokalbefolkningens og naturens interesser.

2. Politikerne i de fem kommunalbestyrelser omkring det Sydfynske Øhav - Svendborg, Langeland, Ærø, FaaborgMidtfyn og Assens har i 2009 besluttet at give ideen om en nationalpark i det Sydfynske Øhav en chance. Borgerne inddrages på kryds og tværs, faglige analyser udarbejdes, og først derefter beslutter politikerne, om de vil sende en ansøgning til ministeren.

3. Øhavsstien, der omkranser det Sydfynske Øhav, er med sine $220 \mathrm{~km}$ en af Danmarks længste vandreruter.

4. Jeg er ikke i besiddelse af det eksakte tal, men det er estimeret ud fra en viden om, at medlemsbladet Fritidsliv udkommer i 8.711 eksemplarer (Dansk Vandrelaug, 2010).

5. I 1997 udarbejdede Friluftsrådet et friluftspolitisk handlingsprogram, som medlemmerne vedtog, og som fortsat danner ramme om rådets arbejde. 